\title{
Role of Cdk5 in Neuronal Signaling, Plasticity, and Drug Abuse
}

\author{
James A. Bibb \\ Department of Psychiatry, University of Texas Southwestern Medical Center, Dallas, Tex., USA
}

\section{Key Words}

Cdk5 - DARPP-32 - Drug abuse $\cdot$ Inhibitor-1 $\cdot$ Kinase $\cdot$

Phosphatase $\cdot$ Plasticity

\begin{abstract}
Functional and structural neuronal plasticity are mediated by a complex network of biochemical signal transduction pathways that control the strength of specific synapses and the formation of new synapses de novo. The neuronal protein kinase $\mathrm{Cdk} 5$ has been implicated as being involved in numerous aspects of both functional and structural plasticity through its regulation of signal transduction pathways. In this review the findings of a number of studies are summarized that have advanced our understanding of how Cdk5 may be involved in these processes. We focus on the modulation of protein phosphatase activity in both the hippocampus and basal ganglia, and review findings that indicate Cdk5 is likely to regulate neuronal plasticity in these brain regions. Studies showing involvement of Cdk5 in reward and motorbased plasticity, which are thought to underlie drug abuse, are discussed.
\end{abstract}

Copyright @ 2003 S. Karger AG, Basel

\section{Introduction}

Intracellular signaling pathways regulate the physiological state of neurons, thereby controlling their excitability and responsiveness. During 'slow' neurotransmission, neurotransmitters released at the synapse activate receptors that are coupled to second messenger signal transduction pathways. An array of interconnected downstream signaling cascades alters various cellular processes that then affect 'fast' neurotransmission mediated by the ligand-gated ion channels associated with action potential generation. Protein phosphorylation and dephosphorylation, mediated by protein kinases and protein phosphatases, respectively, represent predominant biochemical mechanisms by which signals are promulgated. These intracellular regulatory mechanisms control two important features of the CNS, namely structural and functional plasticity. Functional plasticity refers to the regulation of the strength of existing synapses. Structural plasticity refers to the neurobiological processes by which new synaptic connections are made. These processes form the cellular basis for higher brain functions, including learning and memory. The principles of synaptic plasticity have been demonstrated to function in virtually every part of the brain where it has been assessed. The importance of

James A. Bibb, PhD

Department of Psychiatry

University of Texas Southwestern Medical Center

Dallas, TX 75390-9070 (USA)

Tel. +1 214648 4168, Fax +1 214648 1293, E-Mail James.Bibb@UTSouthwestern.edu
Fax +41613061234

E-Mail karger@karger.ch

www.karger.com
Accessible online at:

www. karger.com/nsg 
neuronal plasticity to contextual-based learning and memory in the hippocampus, and in reward and motorbased learning in the dopamine circuitry of the basal ganglia has been well demonstrated. A number of signal transduction mechanisms regulating neuronal plasticity have been reported to be under the control of the neuronal kinase Cdk5. From these studies, a role for this kinase in balancing structural and functional plasticity may be hypothesized.

\section{Functional Plasticity}

Enzymes controlling protein phosphorylation at the synapse are of critical importance for the induction and maintenance of long-term changes in synaptic strength [1]. For example, control of protein dephosphorylation catalyzed by protein phosphatase-1 (PP-1) has been demonstrated to be a key regulatory step in the mediation of long-term potentiation (LTP) and long-term depression (LTD), the most commonly accepted models of synaptic plasticity associated with learning and memory [2-4]. PP-1 is a serine/threonine protein phosphatase that controls the phosphorylation state and activity of numerous downstream effector molecules known to govern synaptic strength, including NMDA receptors [5, 6] and AMPA receptors [7], $\mathrm{Ca}^{2+} /$ calmodulin (CaM)-dependent protein kinase II (CaMKII) [8], and cAMP response elementbinding protein (CREB) [9]. PP-1 activity contributes to the induction of LTD [10] while inhibition of PP-1 has been shown to promote LTP $[11,12]$. Protein phosphatase inhibitor-1 (inhibitor-1) is an endogenous regulator of PP-1 activity [13], and a physiological role for the regulation of PP-1 by inhibitor-1 has been suggested to mediate changes in synaptic strength.

In this model (fig. 1), biochemical cascades form pathways for modulating synaptic strength. Intense NMDA receptor stimulation results in increased intracellular $\mathrm{Ca}^{2+}$ concentrations, which causes activation of $\mathrm{Ca}^{2+}$ / CaM-dependent adenylyl cyclase. Increased cAMP levels result in activation of protein kinase A (PKA) and, in turn, phosphorylation of inhibitor-1 at amino acid residue Thr35. As a result, inhibitor-1 is converted into a potent inactivator of PP-1 $\left(\mathrm{IC}_{50}=1 \mathrm{n} M\right)$. Inhibitor-1-mediated block of PP-1 allows CaMKII to achieve a $\mathrm{Ca}^{2+}$-independent state of activity through autophosphorylation of residue Ser286. This, in turn, results in increased levels of phosphorylation of a number of CaMKII substrates that contribute to increased synaptic strength. Opposing this pathway, low frequency stimulation associated with LTD results in selective activation of protein phosphatase-2B (calcineurin), which maintains inhibitor-1 in a dephosphorylated state. Recently this model has gained support from further studies demonstrating control of synaptic strength through regulation of postsynaptic PP-1 activity by inhibitor-1, as well as other PP-1 regulatory proteins [14]. Furthermore, inhibitor-1 knockout mice are deficient in LTP [15]. Moreover, expression of a constitutively active form of inhibitor- 1 in transgenic mice has been reported to relieve the suppression of learning and memory under the control of PP-1 [16].

Evidence exists to suggest that some of these signaling pathways may be under the control of $\mathrm{Cdk} 5$, thereby implicating this kinase in the control of synaptic strength. For example, $\mathrm{Cdk} 5$ has been demonstrated to phosphorylate inhibitor-1 at Ser67 and reduce the efficiency of its phosphorylation by PKA [17]. Furthermore, the Cdk5 activators p35 and p39 have been shown to interact with CaMKII in a $\mathrm{Ca}^{2+}$-dependent manner [18]. A number of other signaling pathways, such as the Ras/mitogen-activated protein kinase pathway, have been shown to be downstream of NMDA receptors. Furthermore, it is now recognized that a central component of the NMDA receptor signaling complex is the scaffold protein PSD-95 [19]. Moreover, neurotransmitter receptors such as metabotropic glutamate receptors (mGluRs) have been shown to be functionally and structurally associated with NMDA receptors and are involved in LTP [20, 21]. All of these pathways represent additional targets that may be either under the control of, or involved in, Cdk5-dependent modulation of synaptic strength. Indeed, some evidence has been presented to suggest that $\mathrm{Cdk} 5$ phosphorylates, and thereby regulates, the mitogen-activated protein kinase MEK [22] and PSD-95 [23]. It has also been suggested that Cdk5 modulates LTP induction by phosphorylating amino acid residue Ser1232 of the NR2A subunit of the NMDA receptor [24]. Studies also point to the possibility that Cdk5 activity is regulated via mGluR activation [25]. Finally, it has been suggested that Cdk5 can phosphorylate voltage-gated $\mathrm{Ca}^{2+}$ channels, thereby affecting neurotransmitter release [26]. Thus it would appear likely that $\mathrm{Cdk} 5$ is capable of modulating and mediating neuronal functional plasticity through a number of potential signaling pathways. It is through the regulation of these pathways that this protein kinase could contribute to higher brain functions such as learning and memory. Involvement of $\mathrm{Cdk} 5$ in plasticity is evidenced by its involvement in synaptic reorganization during kindling [27]. Furthermore, studies indicated that Cdk5 activity is required for associative learning [28]. However, 


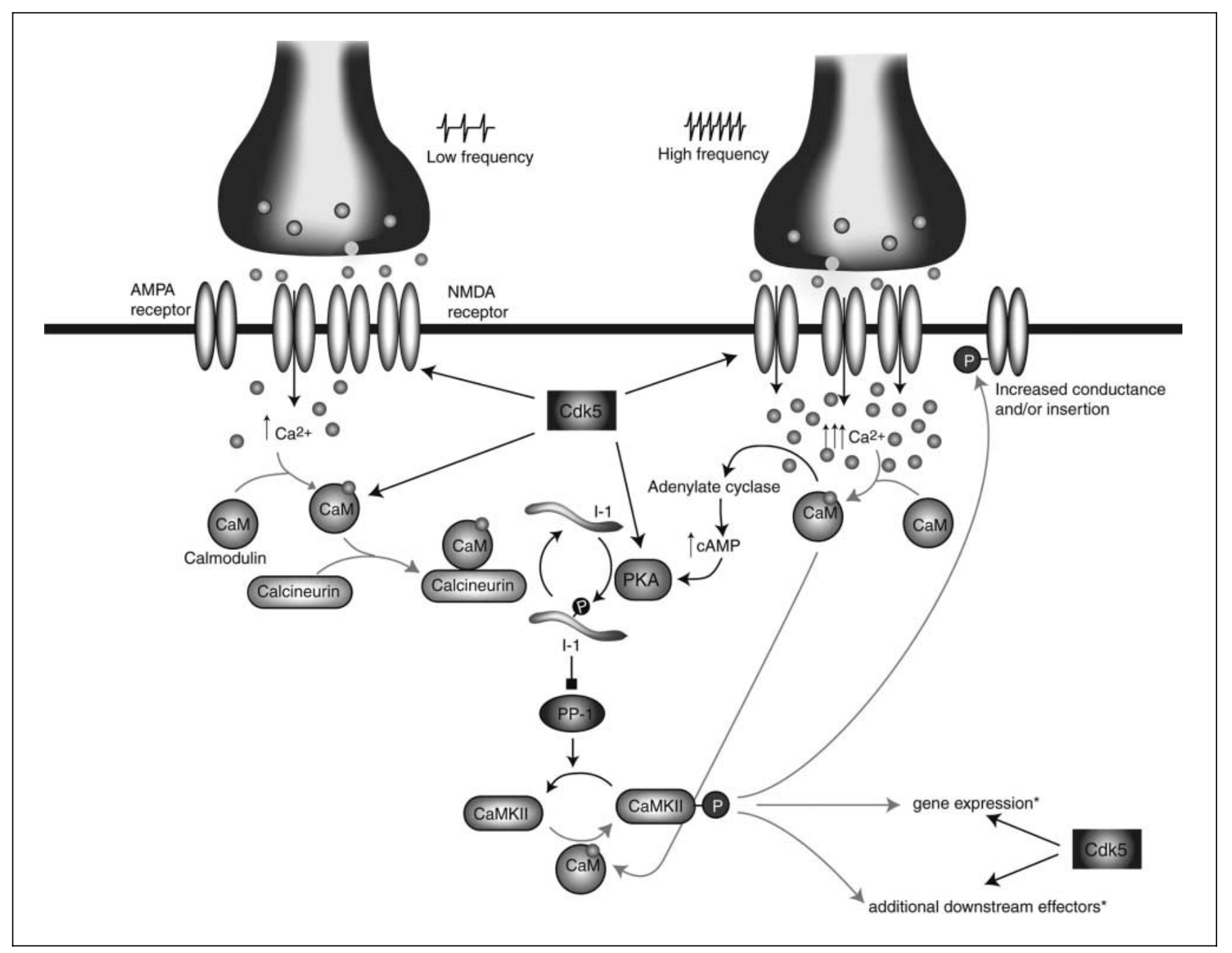

Fig. 1. Signal transduction model of synaptic plasticity. In this model, first proposed by John Lisman, low frequency stimulation of postsynaptic neurons results in a mild increase in intracellular $\mathrm{Ca}^{2+}$ levels, and activation of relatively low amounts of $\mathrm{CaM}$, which bind $\mathrm{Ca}^{2+}$ with high affinity and activate calcineurin, maintaining inhibitor-1 in the dephosphorylated state (left). High frequency stimulation leads to activation of sufficient amounts of CaM to induce $\mathrm{Ca}^{2+} / \mathrm{CaM}$-dependent adenylate-cyclase activation and PKA-dependent phosphorylation of inhibitor-1 at $\mathrm{Thr} 35$ (right). This pathway, in combination with $\mathrm{Ca}^{2+} / \mathrm{CaM}$-dependent activation of CaMKII, causes autophosphorylation of CaMKII at Ser286, thereby allowing the kinase to become CaM-independent and contribute to strengthening of the synapse by a number of pathways. Cdk5 may influence a number of these pathways by, for example, interacting with $\mathrm{CaM}$, phosphorylating NMDA receptors, inhibitor-1, and transcription factors (modified with permission from [95]).

more research is required to clearly elucidate which pathways are under the control of Cdk5. Ultimately, many of the same mechanisms by which Cdk5 functions in CNS development may be retained to facilitate neuronal plasticity in the adult brain.

\section{Structural Plasticity}

While axonal growth cone dynamics have been well characterized [29], it is only recently that dendritic spine motility has been documented [30]. Studies of the visual circuitry have demonstrated that the robust architectural dynamics of neurons in the developing brain are dimin- 
ished in mature adult neurons [31, 32]. Furthermore, spine stability has also been shown to be affected by age [33]. However, it is widely accepted that spine formation and density are regulated by synaptic activity [34, 35], and a recent report demonstrates that spine structural plasticity is retained in the adult brain [36].

Evidence suggests that maintenance of spine morphology requires continual low-level activation of AMPA receptors by spontaneously released glutamate, whereas de novo spine formation is dependent upon NMDA receptor activation with subsequent stabilization by AMPA receptor activation [37, 38]. Coordination of actin cytoskeletal dynamics appears to be essential to structural plasticity. Signaling pathways that involve the Rho family of small GTPases are thought to be key regulators of actin polymerization [39]. Rho family members, including RhoA, Rac1, and Cdc42, have been shown to be involved in dendritic remodeling. Downstream of these proteins are other signaling molecules including PAK (p21 activated protein kinase), and LIM kinase that, in turn, regulate the ability of cofilin to organize actin [40]. Each step in this pathway serves as a potential site for regulation. In addition, many other molecules have been reported to alter spine motility and morphology, including steroid hormones [41], cadherins [42], ephrins [43], neuregulins [44, 45], neurotrophins [46], PSD proteins [47, 48], and cocaine and amphetamines [49-51]. It remains to be seen if all of these diverse pathways converge on a common mechanism such as Rho family GTPases.

A substantial body of research points to a central role for Cdk5 in coordinating cytoskeletal organization and vesicle trafficking associated with changes in neuronal cell morphology and structural plasticity [52-55]. Immunocytochemical studies show that p35 localizes at the cell periphery in lamellipodial and filiopodial structures and is important for neurite outgrowth [56, 57]. Overexpression of p35 and p39 induces actin reorganization [57]. Cdk5 has been shown to induce PAK1 hyperphosphorylation in a Rac-dependent manner, resulting in reduction of PAK1 kinase activity, thereby effecting downstream actin cytoskeletal dynamics. Cdk5 also associates with the actin cross-linking molecule, $\alpha$-actinin- 1 , in a $\mathrm{Ca}^{2+}$-dependent manner [18]. In addition, Cdk5 has been suggested to mediate semaphorin-dependent regulation of actin organization that is essential to dendrite orientation [58]. Furthermore, Cdk5 may affect neurite extension via phosphorylation of MAP1B $[59,60]$. Cdk5 phosphorylates $\beta$ catenin and, in this manner, may function in cadherinmediated adhesion as part of a Cdk5/p35/N-cadherin/ $\beta$ catenin complex $[61,62]$. Moreover, neuregulins have been demonstrated to rely upon Cdk5 to mediate ErbBdependent neuromuscular junction formation [63]. Perhaps Cdk5/ErbB interactions are also important during the formation of central synapses as well.

\section{Neostriatal Signaling}

The principles of neural plasticity, which have been defined in the hippocampus, would appear to apply to the dopamine neurotransmission circuitry of the basal ganglia, which includes the dorsal striatum and nucleus accumbens [64]. It has been well demonstrated that dopamine modulates synaptic plasticity in medium spiny neurons of the striatum [65]. Furthermore, repeated exposure to drugs of abuse that target dopamine neurotransmission has been shown to affect striatal synaptic plasticity [6670].

The striatal specific protein DARPP-32 is an important integrator of signal transduction pathways. DARPP32 , a homologue of inhibitor-1, is converted into a potent inhibitor of PP-1 when phosphorylated by PKA at Thr34 [71]. This pathway is invoked by activation of D1 dopamine receptors [72] and is opposed, as with inhibitor-1 in the hippocampus, by activation of calcineurin that dephosphorylates the PKA site [73]. DARPP-32 is also phosphorylated by Cdk5 at Thr75, which prevents it from being phosphorylated by PKA and causes it to function as an inhibitor of PKA [74]. Thus, the activity of Cdk5 in the striatum would appear to oppose the effects of the dopamine signaling cascade and possibly enhance pathways such as cortical glutamate input, causing increased intracellular $\mathrm{Ca}^{2+}$ levels. Studies using knockout mice have suggested a role for DARPP-32 in regulating striatal LTP and LTD [75]. Furthermore, disruption of corticostriatal plasticity has been associated with increased PKA-dependent phosphorylation of DARPP-32 levels [76]. It is quite likely that, through regulation of the dopamine/PKA/ DARPP-32 pathway, Cdk5 is able to influence plasticity in the striatum.

\section{Drug Addiction}

The transition to the drug-addicted state is increasingly viewed as a consequence of experience-dependent neural and behavioral plasticity $[69,70]$. Addictive drugs act on the brain's natural reward systems, which have evolved to provide advantages to organisms under natural selective pressures [77]. The overwhelming rewarding and rein- 
forcing stimuli of repeated administration of drugs of abuse, such as psychomotor stimulants, result in changes in the neural circuitry of the mesocorticolimbic (and perhaps the nigrostriatal) pathways of the dopaminergic system [49-51]. These changes result in continued drug-seeking and drug administration, despite a variety of deleterious effects.

The mechanisms by which drugs (e.g. nicotine, ethanol, cocaine, amphetamine and opiates) are able to induce addiction vary considerably; nonetheless, similarities exist. For example, all drugs of abuse achieve their action by altering the intracellular signal transduction pathways associated with normal synaptic neurotransmission [78]. Indeed, cocaine causes an increase in synaptic dopamine levels by blocking dopamine reuptake in the basal ganglia, in turn stimulating the dopamine signaling cascade. Repeated exposure to cocaine leads to changes in several components of dopamine signaling, changes in gene expression, and changes in the neuronal circuitry of dopaminoceptive neurons [72, 79-85].

Stimulation by addictive drugs results in a transient burst in immediate early gene expression in the striatum [69, 86-88] (fig. 2). This effect may be mediated partly by CREB, which is also activated in these regions by drugs of abuse. While the activation of CREB and c-Fos may be short-lived, one highly stable Fos family protein, $\Delta$ FosB, has been found to accumulate and persist in striatal neurons in response to chronic exposure to drugs of abuse. The effect of $\Delta$ FosB as a target of drugs of abuse has been characterized by studies using genetically altered mouse models, in which the gene encoding $\Delta$ FosB has been ablated or placed under the control of an inducible striatal specific promoter $[86,89,90]$. DNA microarray analysis of inducible transgenic mice that overexpress $\Delta$ FosB revealed that $\mathrm{Cdk} 5$ is a downstream target of $\Delta \mathrm{FosB}$ in the striatum, including the nucleus accumbens, which is especially implicated in drug addiction [69].

$\mathrm{Cdk} 5$ is a particularly interesting neuromodulatory target of drugs of abuse because, as discussed, it has been shown to regulate dopamine neurotransmission through phosphorylation of DARPP-32 [74]. In agreement with enhanced Cdk 5 expression in inducible $\Delta$ FosB transgenic mice, $\mathrm{Cdk} 5$ expression was found to be upregulated in rat striatum in response to chronic exposure to cocaine [69]. Similarly, mRNA and protein levels of the Cdk5 activator, p35, were also upregulated by induced overexpression of $\Delta \mathrm{FosB}$ and by chronic exposure to cocaine. Once upregulated, $\mathrm{Cdk} 5 / \mathrm{p} 35$ appears to exert an initial desensitizing effect by reducing the efficacy of D1 dopamine receptormediated signaling, as assessed by PKA phosphorylation of specific substrates in striatal slices from rats given chronic cocaine. The overall desensitizing effects of Cdk5 upregulation were also manifested as attenuation in cocaine-induced locomotor behavior. Animals given intraaccumbens infusions of the $\mathrm{Cdk} 5$ inhibitors roscovitine or olomucine exhibited marked elevation in cocaine-induced increases in locomotor behavior in comparison to animals in which vehicle alone or inactive congener was infused. These effects became apparent after 3-4 consecutive days of treatment with cocaine, in agreement with gene expression-dependent adaptations. Thus, Cdk5 activation serves as a negative feedback homeostatic mechanism invoked in response to chronic exposure to cocaine $[69,91]$ (fig. 2). These findings also raised the possibility that $\mathrm{Cdk} 5$ plays a role in the long-term adaptations to cocaine and other drugs of abuse that result in addiction.

The ability of drugs of abuse to cause persistent neural adaptations via altered gene expression may be related to the alterations in the neural circuitry associated with addiction. Structural changes in the neuronal architecture in response to chronic exposure to cocaine and other psychomotor stimulants have been well demonstrated. Repeated stimulant exposure increases the number of dendritic branch points and spines both of medium spiny neurons in the nucleus accumbens and pyramidal neurons in the medial prefrontal cortex [49, 50]. Interestingly, chronic exposure to opiates has the opposite effect on spine density [92], supporting the idea that different drugs of abuse may have opposite effects on common mechanisms of neuronal structural plasticity. Based on this literature, it could be hypothesized that drug-induced changes in Cdk5 gene expression directly mediate the effect of cocaine (and, possibly, other drugs of abuse) on dendritic morphology in the nucleus accumbens. Indeed, the effect of chronic cocaine on spine density in this region was shown to be completely blocked by intra-accumbens infusion of roscovitine [51]. In keeping with the idea that changes in structural plasticity induced by drugs of abuse are dependent on $\mathrm{Cdk} 5$ activity, it has been suggested that opiates, which reduce spine density, cause a reduction in Cdk5 expression in human addicts as well as rats [93]. Finally, it is interesting to consider that the effects of another, arguably addictive, psychomotor stimulant, caffeine, may be mediated via $\mathrm{Cdk} 5$-dependent regulation of dopamine signaling [94]. 


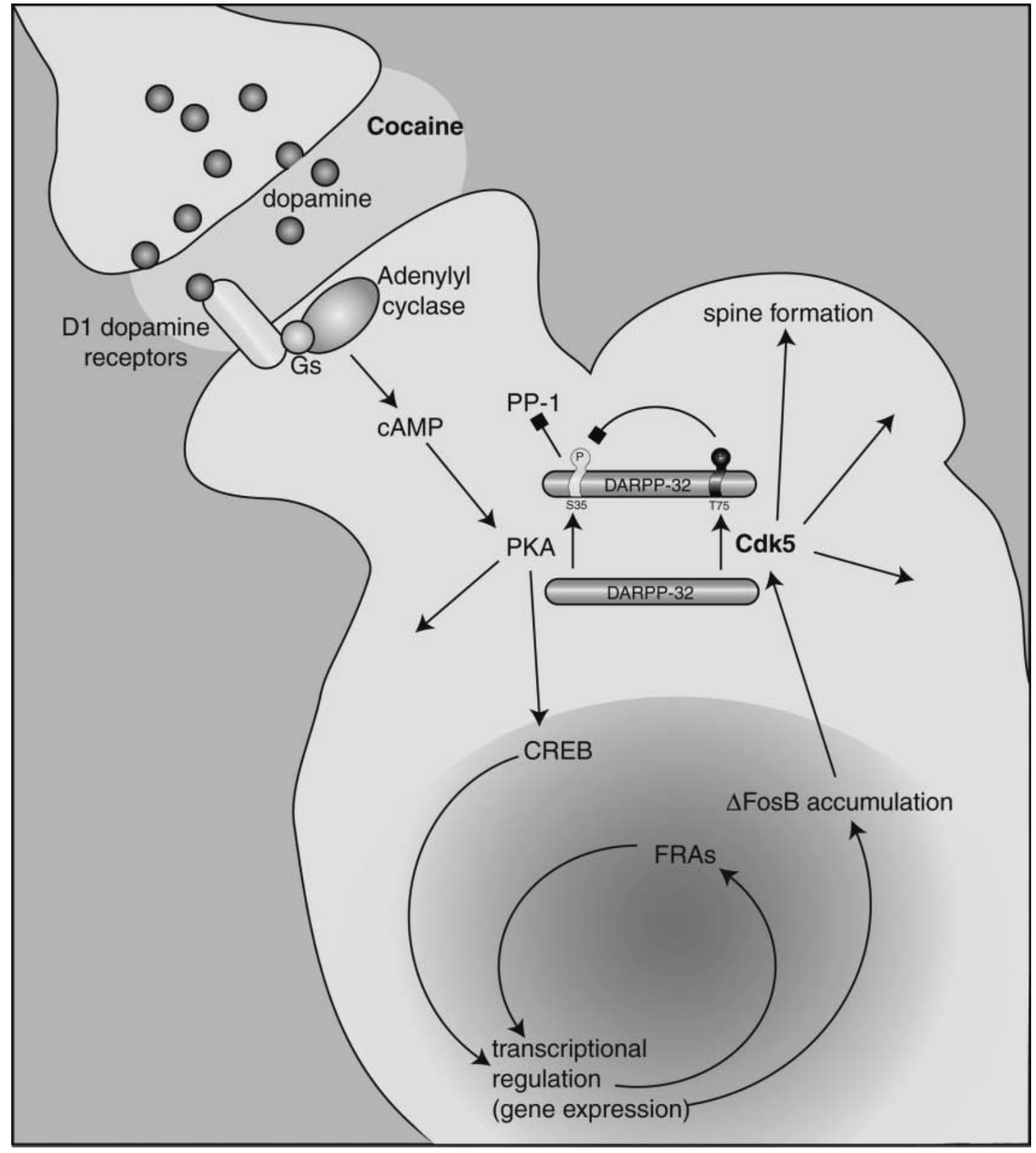

Fig. 2. Schematic of cocaine effects on the dopamine D1 receptor signaling cascade, gene expression, and Cdk5mediated effects. Cocaine enhances dopamine signaling by blocking reuptake of dopamine at the synapse (top). Chronic stimulation of the D1 dopamine receptor/cAMP/PKA pathway leads to PKA-dependent changes in gene expression which target $\mathrm{Cdk} 5$ for upregulation via $\Delta$ FosB. Increased Cdk5-dependent phosphorylation of DARPP-32 at Thr75 results in attenuation of dopamine signaling (functional plasticity) but may commit striatal neurons to adaptive changes in connectivity or spine formation structural plasticity that result in addiction. 


\section{Conclusions}

An integrated and complex network of signaling pathways forms the basis of synaptic plasticity both in the hippocampus and the basal ganglia. Normal, as well as aberrant, neurotransmission modulates neuronal circuitry through these biochemical signaling pathways. Cdk5 activity has now been implicated to affect many of these pathways. In particular, Cdk5 may modulate synaptic strength through its ability to regulate protein phosphatase activity. Therefore, Cdk5 may directly alter both functional and structural plasticity and influence learning and memory. As an example, chronic exposure to cocaine causes overwhelming dopamine D1 receptor stimulation that elicits a Cdk5-dependent homeostatic response (al- tered functional plasticity). However, this response irreversibly dedicates the affected neurons to a process of morphological change and dendritic spine formation (altered structural plasticity), which is also dependent on Cdk5 activity. In this manner, Cdk5-dependent changes in neuroplasticity, which are associated with learning and memory, may result in the formation of the addictive state.

\section{Acknowledgments}

The author would like to acknowledge David R. Benavides for helpful discussions and assistance in the preparation of this manuscript.

\section{References}

1 Tokuda M, Hatase O: Regulation of neuronal plasticity in the central nervous system by phosphorylation and dephosphorylation. Mol Neurobiol 1998;17:137-156.

2 Lisman J: A mechanism for the Hebb and the anti-Hebb processes underlying learning and memory. Proc Natl Acad Sci USA 1989;86: 9574-9578.

3 Lisman J: The CaM kinase II hypothesis for the storage of synaptic memory. Trends Neurosci 1994;17:406-412.

4 Soderling TR, Derkach VA: Postsynaptic protein phosphorylation and LTP. Trends Neurosci 2000;23:75-80.

5 Blank T, Nijholt I, Teichert U, Kugler H, Behrsing H, Fienberg A, Greengard P, Spiess J: The phosphoprotein DARPP-32 mediates cAMP-dependent potentiation of striatal Nmethyl-D-aspartate responses. Proc Natl Acad Sci USA 1997;94:14859-14864.

6 Snyder GL, Fienberg AA, Huganir RL, Greengard P: A dopamine/D1 receptor/protein kinase $\mathrm{A} /$ dopamine- and cAMP-regulated phosphoprotein (Mr $32 \mathrm{kDa}$ )/protein phosphatase-1 pathway regulates dephosphorylation of the NMDA receptor. J Neurosci 1998;18:10297_ 10303.

7 Yan Z, Hsieh-Wilson L, Feng J, Tomizawa K, Allen PB, Fienberg AA, Nairn AC, Greengard P: Protein phosphatase 1 modulation of neostriatal AMPA channels: Regulation by DARPP-32 and spinophilin. Nat Neurosci 1999;2:13-17.

8 Strack S, Choi S, Lovinger DM, Colbran RJ Translocation of autophosphorylated calcium/ calmodulin-dependent protein kinase II to the postsynaptic density. J Biol Chem 1997;272: 13467-13470.
9 Bito H, Deisseroth K, Tsien RW: CREB phosphorylation and dephosphorylation: $\mathrm{A} \mathrm{Ca}(2+)-$ and stimulus duration-dependent switch for hippocampal gene expression. Cell Mol Biol 1996;87:1203-1214.

10 Mulkey RM, Endo S, Shenolikar S, Malenka $\mathrm{RC}$ : Involvement of calcineurin/inhibitor-1 phosphatase cascade in hippocampal long-term depression. Nature 1994;369:486-488.

11 Blitzer RD, Wong T, Nouranifar R, Iyengar R, Landau EM: Postsynaptic cAMP pathway gates early LTP in hippocampal CA1 region. Neuron 1995;15:1403-1414.

12 Blitzer RD, Connor JH, Brown GP, Wong T, Shenolikar S, Iyengar R, Landau EM: Gating of CaMKII by cAMP-regulated protein phosphatase activity during LTP. Science 1998;280: 1940-1942.

13 Huang FL, Glinsmann WH: Separation and characterization of two phosphorylase phosphatase inhibitors from rabbit skeletal muscle. Eur J Biochem 1976;1976:419-426.

14 Morishita W, Connor JH, Xia H, Quinlan EM, Shenolikar S, Malenka RC: Regulation of synaptic strength by protein phosphatase 1 . Neuron 2001;32:1133-1148.

15 Allen P, Hvalby Ø, Jensen V, Ramsay M, Chaudhry FA, Storm-Mathisen J, Morris R, Andersen P, Greengard P: Protein phosphatase-1 regulation in the induction of long-term potentiation: Heterogeneous molecular mechanisms. J Neurosci 2000;20:3537-3543.

16 Genoux D, Haditsch U, Knobloch M, Michalon A, Storm D, Mansuy IM: Protein phosphatase 1 is a molecular constraint on learning and memory. Nature 2001;418:970-975.

17 Bibb JA, Nishi A, O'Callaghan JP, Ule J, Lan M, Snyder GL, Horiuchi A, Saito T, Hisanaga S, Czernik AJ, Nairn AC, Greengard P: Phosphorylation of protein phosphatase inhibitor-1 by Cdk5. J Biol Chem 2001;276:1449014497.
18 Dhavan R, Greer PL, Morabito MA, Orlando LR, Tsai LH: The cyclin-dependent kinase 5 activators p35 and p39 interact with the alphasubunit of $\mathrm{Ca}^{2+}$ /calmodulin-dependent protein kinase II and alpha-actinin-1 in a calciumdependent manner. J Neurosci 2002;22:78797891.

19 Kennedy MB: Signal-processing machines at the postsynaptic density. Science 2000;290: 750-754.

20 Sanes JR, Lichtman JW: Can molecules explain long-term potentiation? Nat Neurosci 1999;2:597-604.

21 Grant SGN, O’Dell TJ: Multiprotein complex signaling and the plasticity problem. Curr Opin Neurobiol 2001;11:363-368.

22 Sharma P, Veerana, Smarma M, Amin ND, Sihag RK, Grant P, Ahn N, Kulkarni AB, Pant HC: Phosphorylation of MEK1 by cdk5/p35 downregulates the mitogen-activated protein kinase pathway. J Biol Chem 2002;277:528534.

23 Morabito MA, Sheng M, Tsai LH: Regulation of PSD-95 multimerization and clustering through direct phosphorylation by Cdk5. Program No 746.7, Abstract Viewer/Itinerary Planner. CD-ROM. Washington, Society for Neuroscience, 2002

24 Li B-S, Sun M-K, Zhang L, Takahashi S, Ma W, Vinade L, Kulkarni AB, Brady RO, Pant HC: Regulation of NMDA receptors by cyclindependent kinase-5. Proc Natl Acad Sci USA 2001;98:12742-12747.

25 Liu F, Ma X-H, Ule J, Bibb JA, Nishi JA, DeMaggio AJ, Yan Z, Nairn AC, Greengard P: Regulation of cyclin-dependent kinase 5 and casein kinase I by glutamate receptors. Proc Natl Acad Sci USA 2001;98:11062-11068. 
26 Tomizawa K, Ohta J, Matsushita M, Moriwaki A, Li S, Takei K, Matsui $\mathrm{H}$ : Cdk5/p35 regulates neurotransmitter release through phosphorylation and downregulation of $\mathrm{P} / \mathrm{Q}$-type voltagedependent calcium channel activity. J Neurosci 2002;22:2590-2597.

27 Tomizawa K, Cai XH, Moriwaki A, Matsushita M, Matsui H: Involvement of cyclin-dependent kinase 5/p35(nck5a) in the synaptic reorganization of rat hippocampus during kindling progression. Jpn J Physiol 2000;50:525-532.

28 Fischer A, Sananbenesi F, Schrick C, Spiess J, Radulovic $\mathrm{J}$ : Cyclin-dependent kinase 5 is required for associative learning. $\mathbf{J}$ Neurosci 2002;22:3700-3707.

29 Tessier-Lavigne M, Goodman CS: The molecular biology of axon guidance. Science 1996;274: 1123-1133

30 Bonhoeffer T, Yuste R: Spine motility. Phenomenology, mechanisms, and function. Neuron 2002;35:1019-1027.

31 Hubel DH, Wiesel TN: Receptive fields of cells in striate cortex of very young, visually inexperienced kittens. J Neurophysiology 1963;26. 994-1002.

32 Hubel DH, Weisel TN: The period of susceptibility to the physiological effects of unilateral eye closure in kittens. J Physiol 1970;206:419_ 436.

33 Grutzendler J, Narayanan K, Gan W-B: Longterm dendritic spine stability in the adult cortex. Nature 2002;420:812-816.

34 Katz LC, Shatz CJ: Synaptic activity and construction of cortical circuits. Science 1996;274: 1133-1138.

35 Yuste R, Bonhoeffer T: Morphological changes in dendritic spines associated with long-term synaptic plasticity. Annu Rev Neurosci 2001; 24:1071-1089.

36 Trachtenberg JT, Chen BE, Knott GW, Feng G, Sanes JR, Welker E, Svoboda K: Long-term in vivo imaging of experience-dependent synaptic plasticity in adult cortex. Nature 2002; 420:788-794.

37 Fischer M, Kaech S, Knutti D, Matus A: Rapid actin-based plasticity in dendritic spines. Neuron 1998;20:847-854.

38 Fischer M, Kaech S, Wagner U, Brinkhaus H, Matus A: Glutamate receptors regulate actinbased plasticity in dendritic spines. Nat Neurosci 2000;3:887-894.

39 Luo L: Actin cytoskeleton regulation in neuronal morphogenesis and structural plasticity. Annu Rev Cell Dev Biol 2002; 18:601-635.

40 Meng Y, Zhang Y, Tregoubov V, Janus C, Cruz L, Jackson M, Lu WY, MacDonald JF, Wang JY, Falls DL, Jia Z: Abnormal spine morphology and enhanced LTP in LIMK-1 knockout mice. Neuron 2002;35:121-133.

41 Woolley C, Gould E, Frankfurt M, McEwen B: Naturally occurring fluctuations in dendritic spine density on adult hippocampal pyramidal neurons. J Neurosci 1990;10:4035-4039.

42 Takeichi M: Cadherins: A molecular family important in selective cell-cell adhesion. Annu Rev Biochem 1990;59:235-252.
43 Ethell IM, Irie F, Kalo MS, Couchman JR, Pasquale EB, Yamaguchi Y: EphB/syndecan-2 signaling in dendritic spine morphogenesis. Neuron 2001;31:1001-1013.

44 Garcia RA, Vasudevan K, Buonanno A: The neuregulin receptor ErbB-4 interacts with PDZ-containing proteins at neuronal synapses. Proc Natl Acad Sci USA 2000;97:3596-3601.

45 Huang K-X, Paudel HK: Ser67-phosphorylated inhibitor 1 is a potent protein phosphatase 1 inhibitor. Proc Natl Acad Sci USA 2000;97: 5824-5829.

46 Horch HW, Kruttgen A, Portbury SD, Katz LC: Destabilization of cortical dendrites and spines by BDNF. Neuron 1999;23:353-364.

47 Hering H, Sheng M: Dendritic spines: Structure, dynamics and regulation. Nat Rev Neurosci 2001;2:880-888.

48 Tomita S, Nicoll RA, Bredt DS: PDZ protein interactions regulating glutamate receptor function and plasticity. J Cell Biol 2001;153: F19-F24.

49 Robinson TE, Kolb B: Alterations in the morphology of dendrites and dendritic spines in the nucleus accumbens and prefrontal cortex following repeated treatment with amphetamine or cocaine. Eur J Neurosci 1999;11:15981604.

50 Robinson TE, Gorny G, Mitton E, Kolb B: Cocaine self-administration alters the morphology of dendrites and dendritic spines in the nucleus accumbens and neocortex. Synapse 2001;39:257-266.

51 Norholm S, Bibb JA, Ouimet CC, Nestler EJ, Taylor JR, Greengard P: Cocaine-induced proliferation of dendritic spines in nucleus accumbens is dependent on the activity of cyclindependent kinase-5. Neuroscience 2003;116: 19-22.

52 Dhavan R, Tsai LH: A decade of CDK5. Nat Rev Mol Cell Biol 2001;2:749-759.

53 Smith DS, Greer PL, Tsai L-H: Cdk5 on the brain. Cell Growth Differ 2001;12:277-283.

54 Smith DS, Tsai L-H: Cdk5 behind the wheel: A role in trafficking and transport? Trends Cell Biol 2002;12:28-36.

55 Tan TC, Valova VA, Malladi CS, Graham ME, Berven LA, Jupp OJ, Hansra G, McClure SJ, Sarcevic B, Boadle RA, Larsen MR, Cousin MA, Robinson PJ: Cdk5 is essential for synaptic vesicle endocytosis. Nat Cell Biol 2003;5: 701-710

56 Nikolic M, Dudek H, Kwon YT, Ramos YF, Tsai LH: The Cdk5/p35 kinase is essential for neurite outgrowth during neuronal differentiation. Genes Dev 1996;10:816-825.

57 Nikolic M, Chou MM, Lu W, Mayer BJ, Tsai $\mathrm{L}-\mathrm{H}$ : The $\mathrm{p} 35 / \mathrm{Cdk} 5$ kinase is a neuron-specific Rac effector that inhibits Pak1 activity. Nature 1998;395:194-198.

58 Sasaki Y, Cheng C, Uchida Y, Nakajima O, Ohshima T, Yagi T, Taniguchi M, Nakayama T, Kishida R, Kudo Y, Ohno S, Nakamura F, Goshima Y: Fyn and Cdk5 mediate semaphorin-3A signaling, which is involved in regulation of dendrite orientation in cerebral cortex. Neuron 2002;35:907-920.
59 Pigino G, Paglini G, Ulloa L, Avila J, Caceres A: Analysis of the expression, distribution and function of cyclin dependent kinase $5(\mathrm{cdk} 5)$ in developing cerebellar macroneurons. J Cell Sci 1997;110:257-270.

60 Paglini G, Pigino G, Kunda P, Morfini G, Maccioni R, Quiroga S, Ferreira A, Caceres A: Evidence for the participation of the neuronspecific CDK5 activator P35 during lamininenhanced axonal growth. J Neurosci 1998;18: 9858-9869.

61 Kwon YT, Gupta A, Zhou Y, Nikolic M, Tsai LH: Regulation of N-cadherin-mediated adhesion by the p35-Cdk5 kinase. Curr Biol 2000; 10:363-372.

62 Kesavapany S, Lau K-F, McLoughlin DM, Brownlees J, Ackerly S, Leigh PN, Shaw CE, Miller CCJ: p35/cdk5 binds and phosphorylates $\beta$-catenin/presenilin-1 interactions. Eur J Neurosci 2001;13:241-247.

$63 \mathrm{Fu} \mathrm{AK}, \mathrm{Fu}$ WY, Cheung J, Tsim KW, Ip FC, Wang JH, Ip NY: Cdk5 is involved in neuregulin-induced AChR expression at the neuromuscular junction. Nat Neurosci 2001;4:374-381.

64 Sung KW, Choi S, Lovinger DM: Activation of group I mGluRs is necessary for induction of long-term depression at striatal synapses. J Neurophysiol 2001;86:2405-2412.

65 Centonze D, Picconi B, Gubellini P, Bernardi G, Calabresi P: Dopaminergic control of synaptic plasticity in the dorsal striatum. Eur $\mathrm{J}$ Neurosci 2001;12:1071-1077.

66 Kalivas PW: Interactions between dopamine and excitatory amino acids in behavioral sensitization to psychostimulants. Drug Alcohol Depend 1995;37:95-100.

67 Clark D, Overton PG: Alterations in excitatory amino acid-mediated regulation of midbrain dopaminergic neurons induced by chronic psychostimulant administration and stress: Relevance to behavioral sensitization and drug addiction. Addict Biol 1998;3:109-135.

68 Wolf ME: The role of excitatory amino acids in behavioral sensitization to psychomotor stimulants. Prog Neurobiol 1998;54:679-720.

69 Bibb JA, Chen J, Taylor JR, Svenningsson P, Nishi A, Snyder G, Yan Z, Sagawa ZK, Quimet CC, Nairn AC, Nestler EJ, Greengard P: Effects of chronic exposure to cocaine are regulated by the neuronal protein Cdk5. Nature 2001;410:376-380.

70 Hyman SE, Malenka RC: Addiction and the brain: The neurobiology of compulsion and its persistence. Nat Rev Neurosci 2001;2:695703.

71 Hemmings HC Jr, Greengard P, Tung HYL, Cohen P: DARPP-32, a dopamine-regulated neuronal phosphoprotein, is a potent inhibitor of protein phosphatase-1. Nature 1984;310: 503-505.

72 Greengard P, Allen PB, Nairn AC: Beyond the dopamine receptor: The DARPP-32/protein phosphatase-1 cascade. Neuron 1999;23:435447.

73 Halpain S, Girault JA, Greengard P: Activation of NMDA receptors induces dephosphorylation of DARPP-32 in rat striatal slices. Nature 1990;343:369-372. 
74 Bibb JA, Snyder GL, Nishi A, Yan Z, Meijer L, Fienberg AA, Tsai L-H, Kwon YT, Girault J-A, Czernik AJ, Huganir RL, Hemmings HC Jr, Nairn AC, Greengard P: Phosphorylation of DARPP-32 by Cdk5 modulates dopamine signaling in neurons. Nature 1999;402:669-671.

75 Calabresi P, Gubellini P, Centonze D, Piccon B, Bernardi G, Chergui K, Svenningsson P, Fienberg AA, Greengard P: Dopamine and cAMP-regulated phosphoprotein $32 \mathrm{kDa}$ controls both striatal long-term depression and long-term potentiation, opposing forms of synaptic plasticity. J Neurosci 2000;20:84438451.

76 Picconi B, Centonze D, Hakansson K, Bernardi G, Greengard P, Fisone G, Cenci MA, Calabresi P: Loss of bidirectional striatal synaptic plasticity in L-DOPA-induced dyskinesia. Nat Neurosci 2003;6:501-506

77 Wise RA: Brain dopamine and reward. Annu Rev Psychol 1989;40:191-225.

78 Koob GF, Nestler EJ: The neurobiology of drug addiction. J Neuropsychiatry Clin Neurosci 1997;9:482-497.

79 Nestler EJ, Berhow MT, Brodkin ES: Molecular mechanisms of drug addiction: Adaptations in signal transduction pathways. Mol Psychiatry 1996;1:190-199.

80 Nestler EJ, Aghajanian GK: Molecular and cellular basis of addiction. Science 1997;278:5863.
81 Berke JD, Paletzki RF, Aronson GJ, Hyman SE, Gerfen CR: A complex program of striatal gene expression induced by dopaminergic stimulation. J Neurosci 1998; 18:5301-5310.

82 Nestler EJ: Genes and addiction. Nat Genet 2000;26:277-281.

83 Freeman WM, Nader MA, Nader SH, Robertson DJ, Gioia L, Mitchell SM, Daunais JB, Porrino LJ, Friedman DP, Vrana KE: Chronic cocaine-mediated changes in non-human primate nucleus accumbens gene expression. J Neurochem 2001;77:542-549.

84 Nestler EJ: Molecular basis of long-term plasticity underlying addiction. Nat Rev Neurosci 2001;2:119-128.

85 Nestler EJ, Landsman D: Learning about addiction from the genome. Nature 2001;409: 834-835.

86 Kelz MB, Chen J, Carlezon WA Jr, Whisler K, Gilden L, Beckmann AM, Steffen C, Zhang YJ, Marotti L, Self DW, Tkatch T, Baaranauskas G, Surmeier DJ, Neve RL, Duman RS, Picciotto MR, Nestler EJ: Expression of the transcriptional factor $\Delta$ FosB in the brain controls sensitivity to cocaine. Nature 1999;401:272-276.

87 Bibb JA, Chen J, Taylor JR, Svenningsson P, Nishi A, Snyder GL, Yan Z, Sagawa ZK, Nairn AC, Nestler EJ, Greengard P: Regulation of the effects of cocaine by $\mathrm{Cdk} 5$ in dopaminoceptive neurons in the brain. Nature 2000;410:376380.

88 Chen J, Zhang Y-J, Kelz MB, Steffen C, Ang ES, Zeng L, Nestler EJ: Induction of cyclindependent kinase 5 in the hippocampus by chronic electroconvulsive seizures: Role of $\Delta$ FosB. J Neurosci 2000;10:8965-8971.
89 Brown JR, Ye H, Bronson RT, Dikkes P, Greenberg ME: A defect in nurturing in mice lacking the immediate early gene fosB. Cell 1996;86:297-309.

90 Hiroi N, Brown JR, Haile CN, Ye H, Greenberg ME, Nestler EJ: FosB mutant mice: Loss of chronic cocaine induction of Fos-related proteins and heightened sensitivity to cocaine's psychomotor rewarding effects. Proc Natl Acad Sci USA 1997;94:10397-20402.

91 Gupta A, Tsai LH: A kinase to dampen the effects of cocaine? Science 2001;293:277-283.

92 Robinson TE, Gorny G, Savage VR, Kolb B: Widespread but regionally specific effects of experimenter- versus self-administered morphine on dendritic spines in the nucleus accumbens, hippocampus, and neocortex of adult rats. Synapse 2002;46:271-279.

93 Ferrer-Alcon M, La Harpe R, Guimon J, Garcia-Sevilla JA: Downregulation of neuronal cdk5/p35 in opioid addicts and opiate-treated rats: Relation to neurofilament phosphorylation. Neuropsychopharmacology 2003;28:947955.

94 Lindskog M, Svenningsson P, Pozzi L, Kim Y, Fienberg AA, Bibb JA, Fredholm BB, Nairn AC, Greengard P, Fisone G: Involvement of DARPP-32 phosphorylation in the stimulant action of caffeine. Nature 2002;418:774-778.

95 Winder DG, Sweatt JD: Roles of serine/threonine phosphatases in hippocampal synaptic plasticity. Nat Rev Neurosci 2001;2:461-474. 